\title{
OFR: $63-29$
}

Form 9-014

\section{UNITED STATES \\ DEPARTMENT OF THE INTERIOR \\ GEOLOGICAL SURVEY

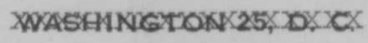

Albuquerque, N. Mex.

Water-Supply Developement at the

d National Aeronautics and space Agency -

Apollo Propulsion System Development facility,

Dona Ana County, N. Mex.

By

G. C. Doty

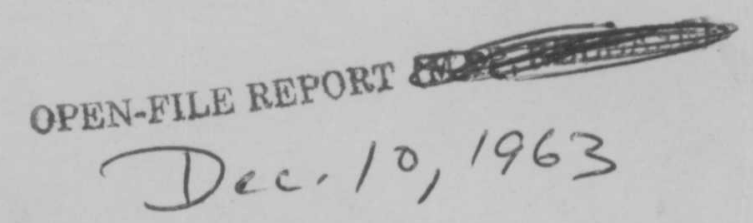

Prepared in cooperation with the U. S. Army, Corps of Engineers

- Administrative report

October 1963

U. S. GOVERMMENT PRINTING OFFICE $16-68863-2$ 
United States

Department of the Interior

Geological Survey

Albuquerque, New Mexico

Water-Supply Development at the

National Aeronautics and Space Agency -

Apollo Propulsion System Development facility,

Dona Ana County, N. Mex.

By

G. C. Doty

Prepared in cooperation with the U.S. Army, Corps of Engineers

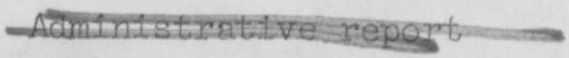

October 1963 


\section{Contents}

Page

Summary of events

Methods and procedures

Geology and ground water occurrence 3

Aquifer tests

Chemical quality of water 5 
Illustrations

Page

Figure 1.--General location of NASA-Apollo PSD facility and sites of wells, Dona Ana County, N. Mex.

$1 \mathrm{a}$

2.--Drawdown and recovery of water and pumping rate during pumping test at well I, May I-2, $1963 \ldots 4$ a

3.--Drawdown and recovery of water level and pumping rate during pumping test at well J, May 30-31, $1963 \ldots . .-$ $4 \mathrm{~b}$

4. Water-level recovery data for test at well I on

May 1-2, 1963

$4 c$

5.--Water-level recovery data for test at well $\mathrm{J}$ on

May $30-31,1963$

$4 d$

iii 


\section{Tables}

Page

Table 1.--Records of wells drilled at Apollo PSD facility,

Dona Ana County, N. Mex.

2.--Descriptions of cuttings from wells at Apollo PSD

facility, Dona Ana County, N. Mex.

3.--Electric logs of wells C, D, H, I, and $J$ in the Apollo

PSD facility, Dona Ana County, N. Mex.

Well C - Electrical log.

Well D - Electrical log.

Well H - Electrical log.

Well I - Microlog (with caliper).

Well I - Induction-Electrical log.

Well J - Microlog (with caliper).

Well J - Induction-Electrical log.

4.--Analyses of water samples from wells C, D, G, and H, Apollo PSD, by commercial laboratory for NAA -.....--

5.--Analyses of water samples from wells I and J, Apollo PSD, by U.S. Geological Survey 
Water-Supply Development at the National Aeronautics and

Space Agency - Apollo Propulsion System Development Facility,

Dona Ana County, $\mathbb{N}$. Mex.

By

G. C. Doty

Summary of events

A water requirement of $300 \mathrm{gpm}$ (gallons per minute) per 16 hour day was scheduled for the NASA-Apollo PSD (National Aeronautics and Space Agency-Apollo Propulsion System Development) facility to be built about 8 miles north of Organ, $\mathbb{N}$. Mex., in the Jornada del Muerto on the west flank of the San Andres Mountains. In an effort to establish this water requirement NAA (North American Aviation Company) under contract from NASA, caused four exploratory wells (C, D, G, and H) to be drilled on the fan slope of the San Andres Mountains near the proposed location of the facility. The general location of the area and the sites of wells are shown in figure 1 . The sites for wells $C, D, G$, and H were selected

Figure 1.--General location of NASA-Apollo PSD facility and sites of wells, Dona Ana County, N. Mex.

by NAA from recommendations made by the Ralph M. Parsons Company.

The U.S. Corps of Engineers assumed responsibility for the water supply at the Apollo PSD facility on April 1, 1963 and requested the services of the USGS (U.S. Geological Survey) in evaluating the water problem. After a review of file data, examination of the records and drill cuttings from the wells drilled for NAA, and a visit to the Jornada del Muerto area, the USGS selected a site for a fifth well (I) (fig. l) and also monitored the reaming, developing, and testing of well $\mathrm{C}$. The yield from well $\mathrm{C}$ was inadequate and the USGS selected a site for a sixth well (J) (fig. 1). Drilling and testing of wells $I$ and $J$ were supervised by USGS personnel. 
R. 3 E.

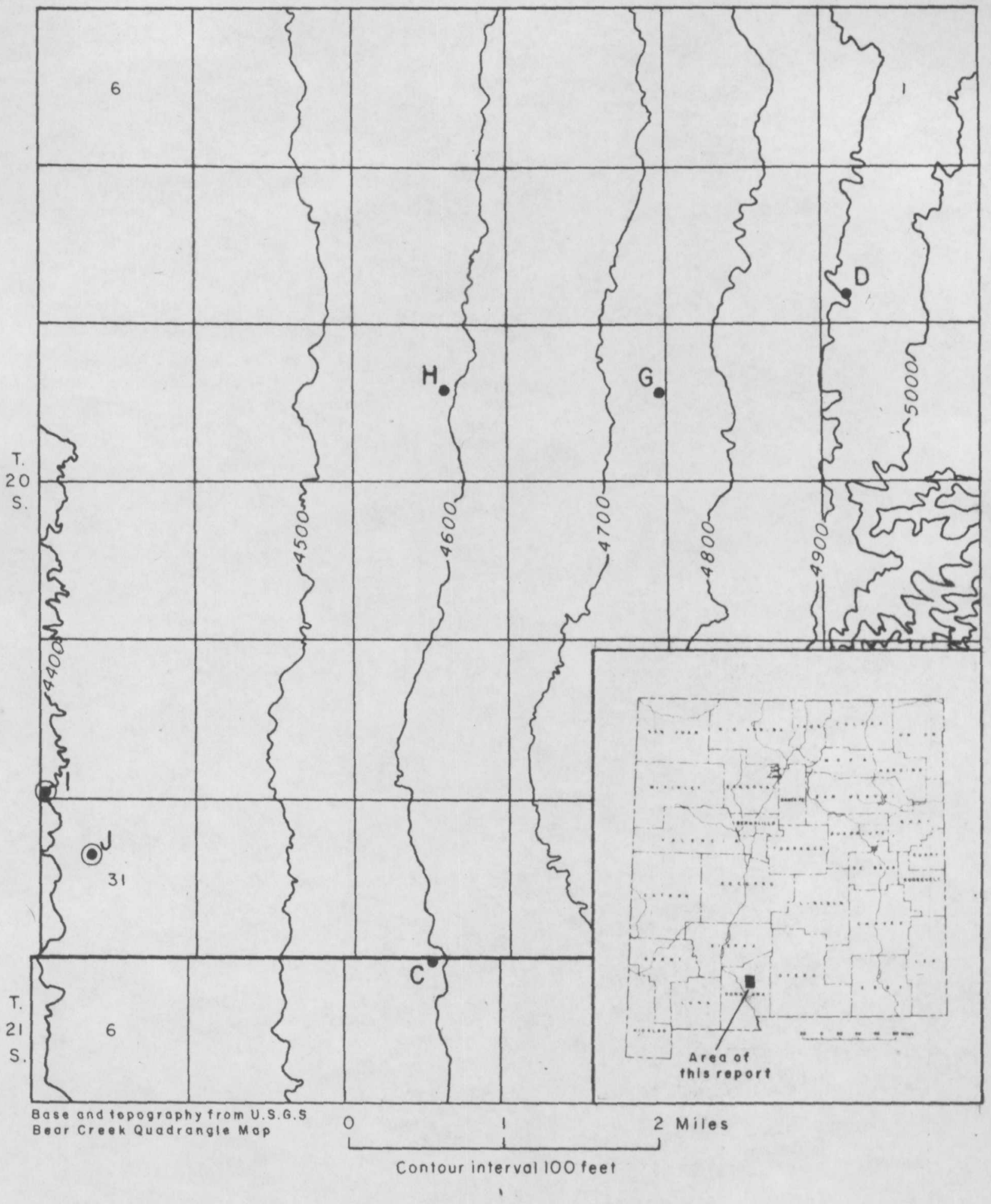

EXPLANATION

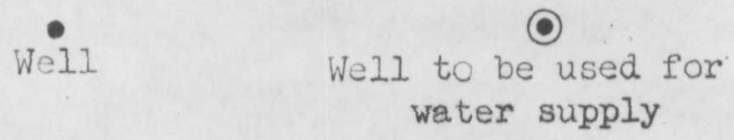

Figure 1.--General location of NASA-Apollo PSD facility and sites of wells, Dona Ana County, N. Mex. 


\section{Methods and procedures}

All wells at the Apollo PSD facility were drilled by the hydraulic rotary method by the Layne-Texas Company. Drilling operations began in December 1962 at well C and ended in May 1963 at well J (table l). Sample descriptions of the cuttings from wells C, D, G, and H were prepared by USGS personnel after the wells were drilled; descriptions of cuttings were made during the drilling of wells $I$ and $J$ (table 2). An electric log was made of each well except $G$ (table 3). Wells $C, I$, and $J$ were reamed to 16-inch diameter, cased with $12-3 / 4-$ inch oD steel casing and developed by bailing and surging. The water level in well $C$ was lowered so much by bailing that further testing was unnecessary and the well was abandoned. Water samples were collected by air jetting through the drill stem and from the discharge pipe of wells in which test pumps were installed. 
Geology and ground water occurrence

The Jornada del Muerto is a topographic basin whose southern extremity, in which the Apollo PSD facility lies, is between the Dona Ana and San Andres Mountains. The rocks exposed in these mountains on either side of the basin have been eroded, f1lling the basin to an unknown depth. The sediments in this basin include the Santa Fe Group of middle(?) Miocene to Pleistocene(?) age and Recent alluvium; they are hereinafter referred to as bolson deposits.

The bolson deposits consist of irregular beds and lenses of unconsolidated to semi-consolidated clay, silt, sand, and gravel, and mixtures of these particle sizes. Wells in the Jormada obtain water, which is unconfined or semiconfined, from permeable beds of sand and gravel in the bolson deposits. The bolson deposits and the saturated zone within the deposits thin toward the mountains: thus the probability of obtaining an adequate supply of water decreases with nearness to the mountains. Wells $C, D, G$, and H apparently did not penetrate a sufficient thickness of saturated bolson deposits to yield the required quantity of water. Wells I and $J$ penetrated 682 and 602 feet of saturated bolson deposits, respectively, and when cased as water wells, each had 400 feet of slotted casing open to the saturated sections. 


\section{Aquifer test}

Wells I and $\mathrm{J}$ were test pumped at approximately I,000 gpm (gallons per minute) for 24 hours with a turbine pump driven by a gas powered motor. Water levels were measured with an electric tape during drawdown and recovery (figs. 2 and 3 ). The discharge fluctuated throughout the

Figure 2.--Drawdown and recovery of water level, and pumping rate during 24-hour pumping test at well I, May 1-2, 1963.

Figure 3.--Drawdown and recovery of water level, and pumping rate during pumping test at well J, May 30-31, 1963.

tests due to variances in speed of the motor, and the drawdown part of each test is of little value for computing aquifer characteristics. A semi-log plot of water-level recovery versus time indicates the coefficient of transmissibility is about 48,000 gpd (gallons per day) per ft for well I and about $80,000 \mathrm{gpd}$ per ft for well J (figs. 4 and 5).

Figure 4.--Water-level recovery data for test at well I on

May $1-2,1963$.

Figure 5.--Water-level recovery data for test at well $\mathrm{J}$ on

May $30-31,1963$.

The coefficients of transmissibility are on the order of those expected from bolson deposits, and the relatively small drawdown of water levels indicates that the wells are in good hydraulic connection with the aquifer. 

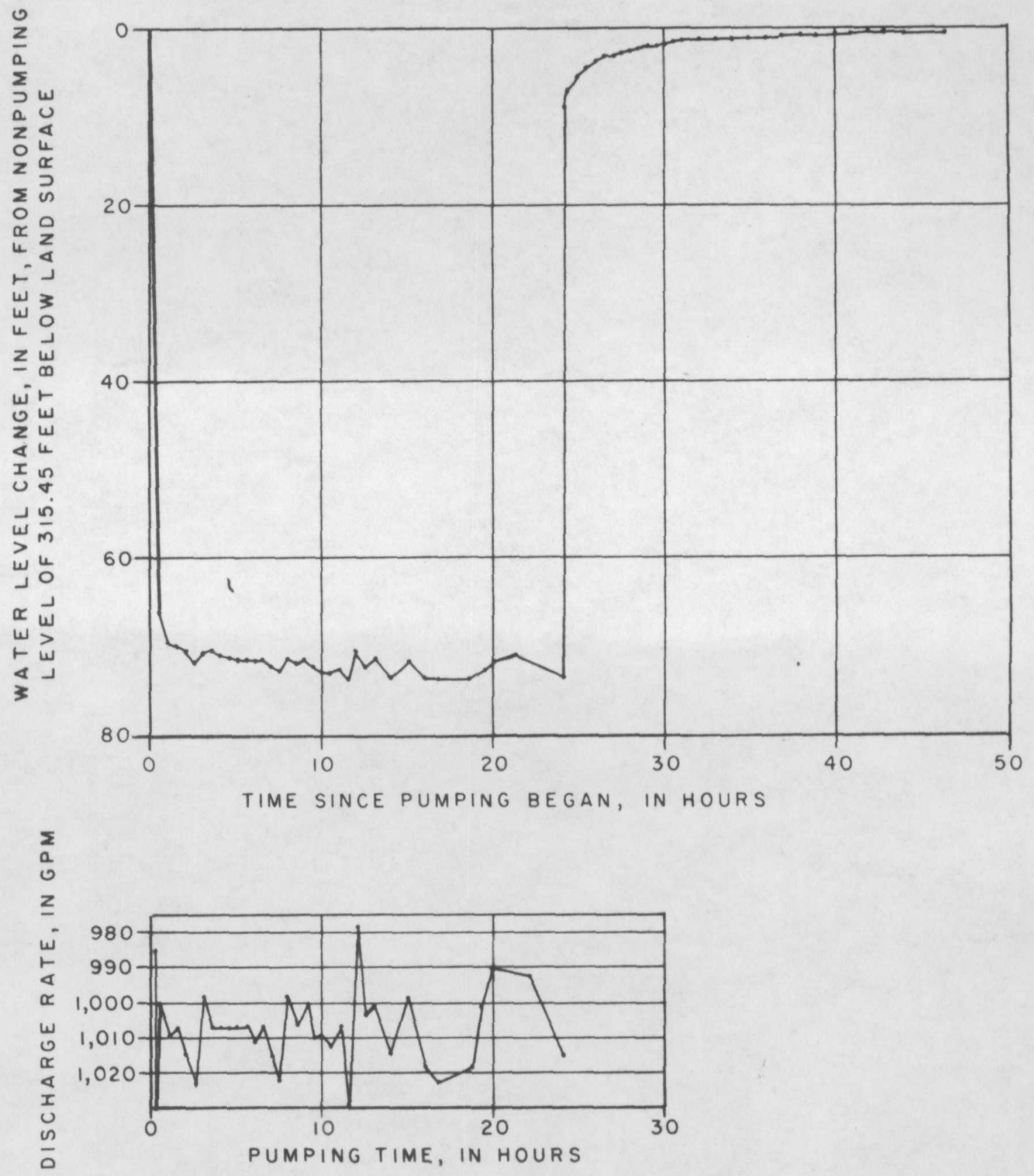

Fis.a2--Drawdown and recovery of water level and pumping rate during pumping test at well I, May 1-2, 1963. 


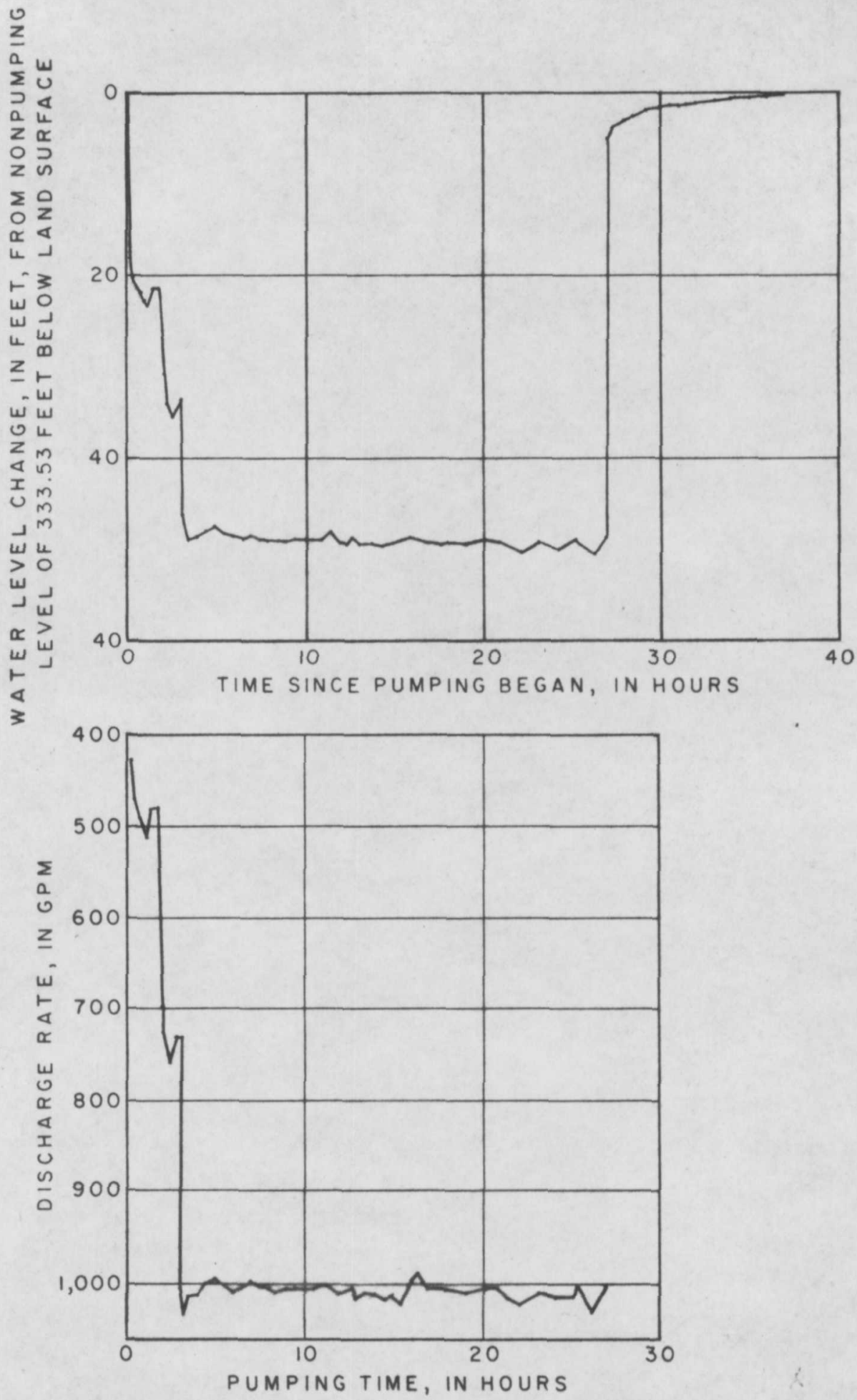

Fig. 3.--Drawdown and recovery of water level and pumping rate during pumping test at well J, May 30-31, 1963. 
RESIDUAL DRAWDOWN, IN FEET OF WATER

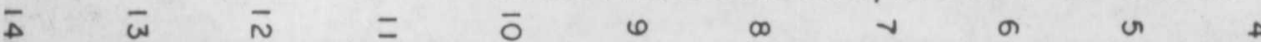

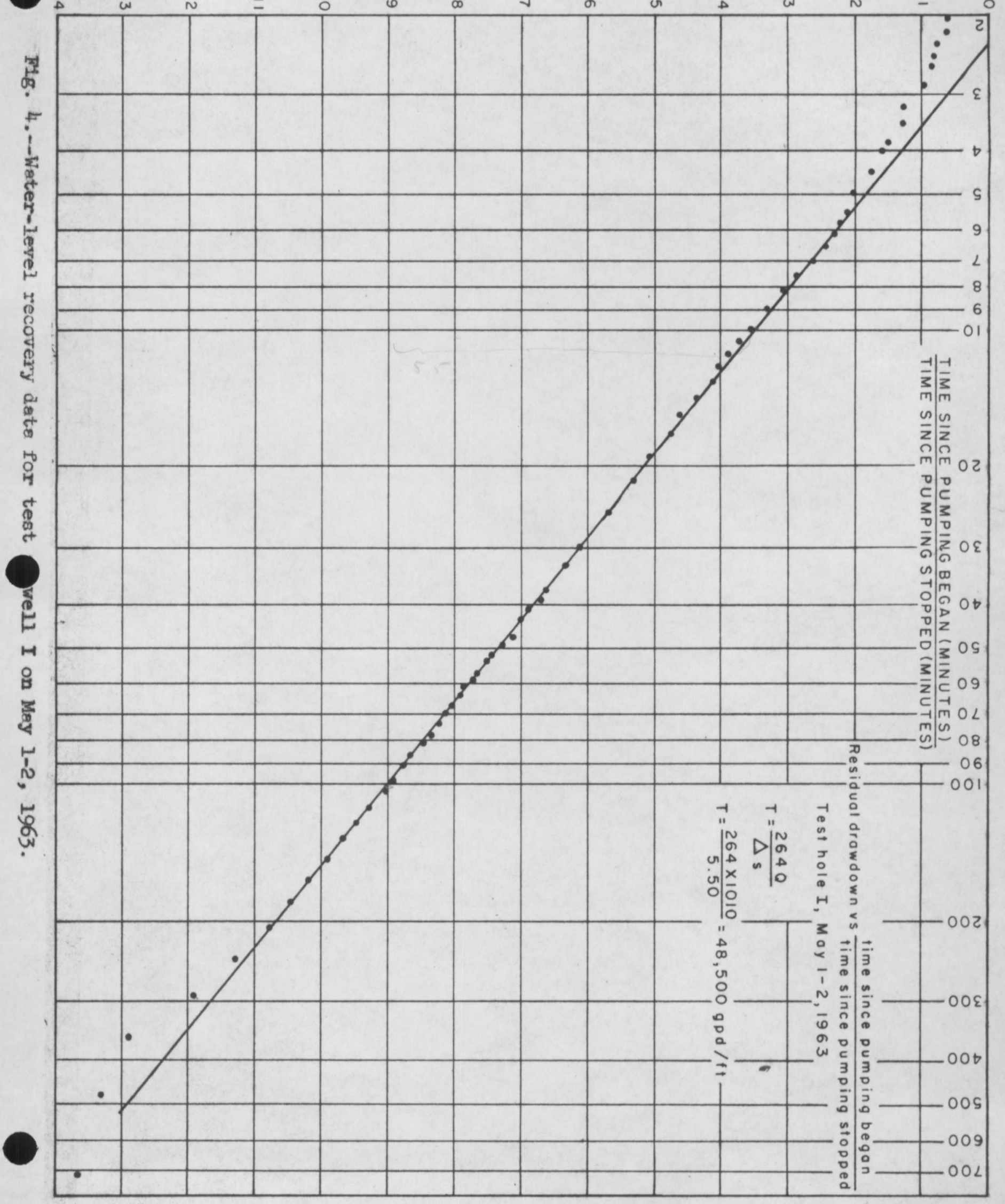


RESIDUAL DRAWDOWN, IN FEET OF WATER

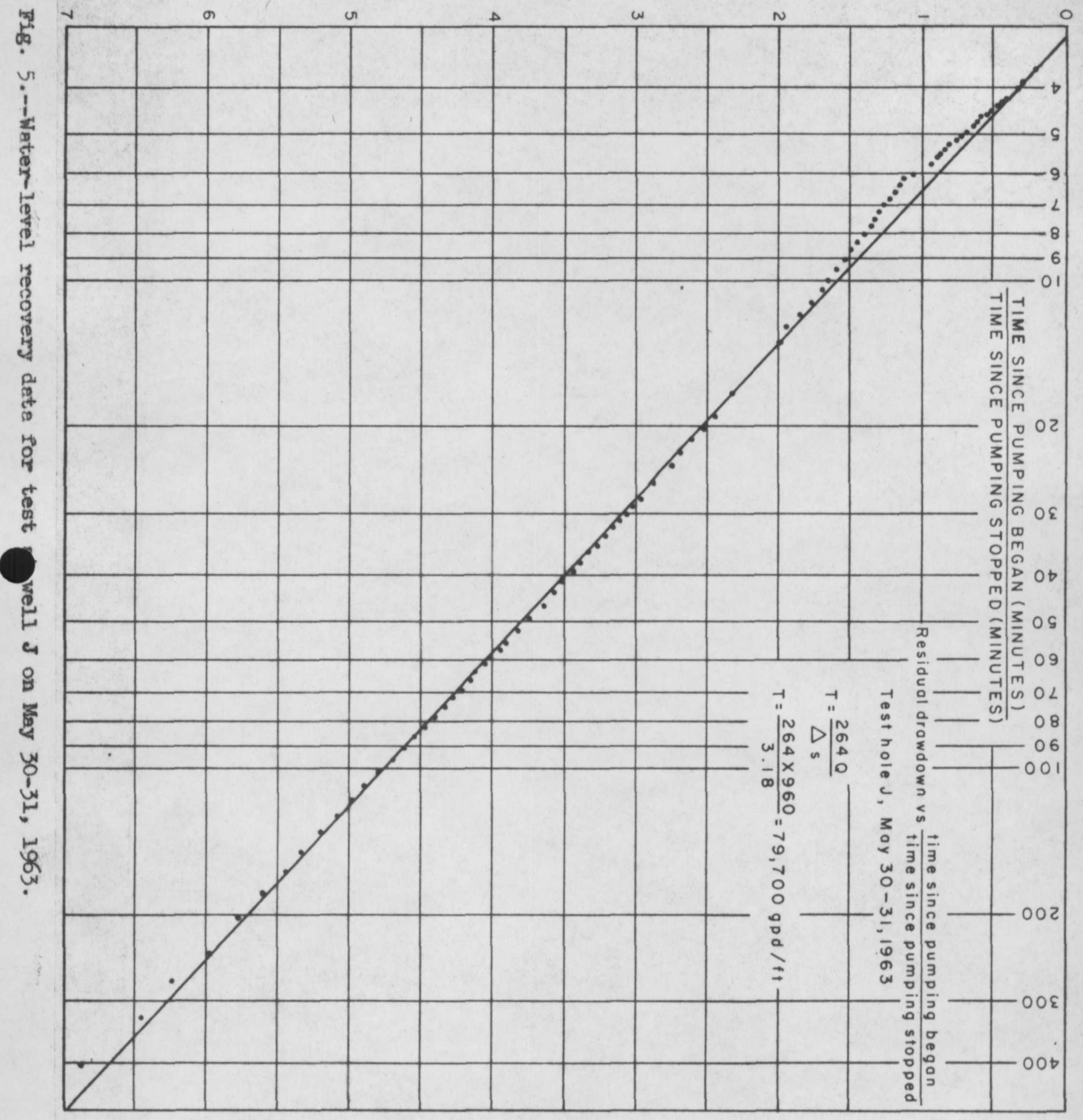


The chemical quality of ground water in the Jornade ranges widely. Sulfate is the principal contaminent in water of poor quality. The sulfate is derived from gypsum that weathers out of rocks exposed in the San Andres Mountains. The quality of water from the Apollo PSD facility wells is shown in tables 4 and 5 . The anslyses of water from wells C, D, G, and $\mathrm{H}$ were made by an independent laboratory for NAA (table 4); the anslyses of water from wells I and $J$ were made by the U.S. Geological Survey laboratory (table 5).

The sulfate content of water from 811 the wells except $C$ was above the U.S. Public Health Service recommended limits of $250 \mathrm{ppm}$ (parts per million). The water from wells $I$ and $J$ contains about 300 ppm sulfate and is therefore inferior water by Public Health Service standards. The water is extremely hard; the hardness as $\mathrm{CaCO}_{3}$ of water from wells $I$ and $J$ is 378 and $418 \mathrm{ppm}$, respectively. Water of appreciably better quality probably cannot be obtained within a reasonable distance of the facility; water of comparable quality with that from $I$ or $J$ is widely used for domestic and municipal supplies in New Mexico. 
Table 1.--Records of wells drilled at Apollo PSD

facility, Dona Ana County, N. Mex.

Well C

Location: NW $\frac{1}{4} N W \frac{1}{4} N E \frac{1}{4}$ sec. 4, T. 21 S., R. 3 E., Dona Ana County, N. Mex.

Altitude: Land-surface altitude ",590 feet above sea level datum, interpolated from USGS topographic maps.

Depth: 1,011 feet below land surface datum.

Date completed: April 22, 1963 (Plugged and abandoned)

Drilling contractor: Layne-Texas Co., El Paso, Tex.

Drilling method: Hydraulic rotary

Casing and well record: 8-inch test well drilled to 1,011 feet December $6-18,1962$. Well reamed to $16-$ inch and cased full depth with 12 3/4-inch casing March 27 to April 15, 1963. Casing perforated with 3/16 $\times 2$-inch mill-cut slots, 12 slots around, staggered rows, from 350-460, 590-650, 690-720, and 800-1,000 feet. 24-inch surface casing cemented to 30 feet.

Well completion record: 12 3/4-inch casing pulled and well plugged with heavy mud and abandoned April 22, 1963. Steel cap welded on surface casing. 


\section{Table 1.--Records of wells - Continued \\ We11 C - Continued}

Geologic source:

Probably bolson deposits, from 360 to 450

feet. Water level was lowered from 362 to

752 feet by bailing at a rate of about 38

gpm with 90-gallon bailer indicating that

the well was incapable of producing the desired yield.

Formation logs: (1) Sample description (2) Electrical log. See table 3. Water sample: See table 4.

Summary of material penetrated: See table 2.

Material

Depth interval (feet)

Bolson deposits

$$
0-453
$$

Igneous rock (weathered)

$453-503$

Igneous rock (unweathered)

503-1,011 
Table 1.--Records of wells - Continued

Well D

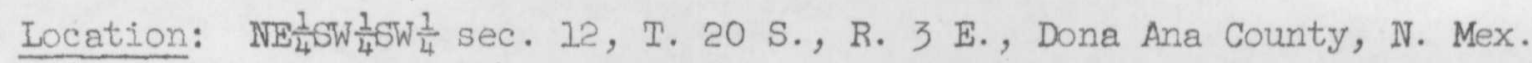
Altitude: Land-surface altitude 4,900 feet above sea level datum, interpolated from USGS topographic maps.

Depth: 1,321 feet below land surface datum

Date completed: January 24, 1963

Drilling contractor: Layne-Texas Co., El Paso, Tex.

Drilling method: Hydraulic rotary

Casing and well record: 8-inch well to 1,321 feet, not cased.

Well completion record: Plugged and abandoned

Geologic source: Unknown. Yield insufficient to justify further development.

Formation logs: (1) Sample description (2) Electrical log. See table 3. Water sample: See table 4.

Summary of material penetrated: See table 2 .

Material

Depth interval (feet)

Bolson deposits

$0-265$

older sedimentary rocks.

$265-1,319$ 


\section{Table 1.--Records of wells - Continued}

\section{Well G}

Location: $\quad N_{E} \frac{1}{4} \operatorname{NE} \frac{1}{4} \mathrm{SE} \frac{1}{4} \mathrm{sec} .15$, T. 20 S., R. 3 E., Dona Ana County, N. Mex. Altitude: Land-surface altitude 1,710 feet above sea level datum, interpolated from USGS topographic maps.

Depth: 578 feet below land surface datum

Date completed: February 8, 1963

Drilling contractor: Layne-Texas Co., El Paso, Tex.

Drilling method: Hydraulic rotary

Casing and well record: 8-inch well to 578 feet, not cased.

Well completion record: Plugged and abandoned.

Geologic source: Unknown. Yield insufficient to justify further development.

Formation logs: (1) Sample description

Water sample: See table 4.

Summary of material penetrated: See table 2 .

Material

Depth interval (feet)

Bolson deposits $0-180$

Volcanic rocks - $180-250$

Limestone and shale 
Table 1.--Records of wells - Continued

Well H

Location: SW $\frac{1}{4} \operatorname{SW} \frac{1}{4} \operatorname{NE} \frac{1}{4} \mathrm{sec} .16$, 1. 20 S., R. 3 E., Dona Ana County, N. Mex. Altitude: Land-surface altitude i,590 feet above sea level datum, interpolated from USGS topographic map.

Depth: 1,445 feet below land-surface datum

Date completed: March 2, 1963

Drilling contractor: Layne-Texas Co., El Paso, Tex.

Drilling method: Hydraulic rotary

Casing and well record: 10 -inch well to 1,445 feet. 6-inch casing wedged in well at 350 feet, and could not be pulled or driven.

Well completion record: Plugged and abandoned.

Geologic source:

Probably bolson deposits. Water level lowered from 272 to 739 feet by pumping at $35 \mathrm{gpm}$ with submergible punp.

Formation logs: (1) Sample description (2) Electrical log. See table 3. Water sample: See table 4.

Sunmary of material penetrated: See table 2 .

$$
\text { Material. }
$$

Depth interval (feet)

Bolson deposits

$$
0-285
$$

Igneous rock (weathered)

$285-335$

Igneous rock (unweatherec)

$335-1,445$ 


\section{Table 1.--Records of wells - Continued}

\section{Well I}

Location: SW $\frac{1}{4} S W \frac{1}{4} S W \frac{1}{4}$ sec. 30 , T. 20 S., R. 3 E., Dona Ana County, N. Mex.

Altitude: Land surface altitude, 4,385 above sea level datum, interpolated from USGS topographic map.

Depth: 862 feet below land surface

Date completed: May 2, 1963

Drilling contractor: Layne-Texas Co., El Paso, Tex.

Drilling method: Hydraulic rotary

Casing and well record: 8-inch test well drilled to 1,000 feet. 30 feet of 18-inch surface casing cemented in and well reamed to $16-$ inch to 862 feet. Well cased full depth with 862 feet of $123 / 4$-inch casing perforated from 130-660 and 680-850 feet with 3/16 x 2-inch mill cut slots, 12 slots around, alternate rows staggered.

Well completion record: Fitted with temporary steel cap.

Geologic source:

Bolson deposits. Water level lowered from 318 to 391 feet by pumping for 24 hours at rate of 1,000 gpm.

Formation logs: (1) Sample description (2) Microlog and inductionelectrical logs. See table 3 .

Water sample: See table 5 .

Summary of material penetrated: See table 2 .

1,000 feet of bolson deposits. 
Table 1.--Records of wells - Concluded

\section{Wel. $\mathrm{J}$}

Location: NW $\frac{1}{4} S E \frac{1}{4} N W \frac{1}{4} \mathrm{sec} .31$, T. 20 S., R. 3 E., Dona Ana County, N. Mex. Altitude: Land surface altitude 1,410 feet above ser level datum, interpolated from USGS topographic map.

Depth: 850 feet below land surface

Date completed: May 31, 1963

Drilling contractor: Layne-Texas Co., EI Paso, Tex.

Drilling method: Hydraulic rotary

Casing and well record: 10-inch test well drilled to 939 feet. 30 feet of 18-inch surface casing cemented in and well reamed 16 -inch to 850 feet. $123 / 1$-inch casing installed to full depth. Casing perforations: mill-cut $3 / 16 \times 2$-inch slots. 12 slots around, staggered rows. Perforated interva]s: 400-700, 740-840 feet.

Well completion record: Fitted with temporary steel cap. Geologic source: Bolson deposits. Water level lowered from 337 to 388 feet by purping at rate of 1,000 gpm for 24 hours.

Formation logs: (1) Sample description (2) Microlog and induction electrical log: See table 3.

Water sample: See table 5 .

Summary of material penetrated: See table 2 .

939 feet of bolson deposits. 
Table 2.--Descriptions of cuttings from wells at Apollo PSD facility, Dona Ana County, N. Mex.

\section{WeII C}

Location: NW $\frac{1}{4} N W \frac{1}{4} N E \frac{1}{2}$ səc. 4 , T. 21 S., R. 3 E.

Material

No sample taken

Pebbles, dark-gray to black, and limestone.......

No sample taken

Silt, light-brown with limestone, gravel and

pebbles to $\frac{1}{2}$ inch

Gravel, with limestone pebbles to $\frac{1}{2}$ inch, in

light-brown clay matrix-n...

Silt, light-brown, with limestone pebbles to

$\frac{1}{2}$ inch

Silt, light arown with small anglar gravels

Depth interval (feet)

Sand to small pebbles, light-gray and cream,

angular to sub angular

Sand and limestone pebbles to $\frac{1}{4}$ inch, angular....

Sand and limestone pebbles to 1 inch, angular...-

Silt, light -orown with small limestone gravel....

Sand to small pebble size particles, li ht- ray

and cream, angular to sub angular

$$
0-20
$$

$20-25$

$$
25-30
$$

$$
30-40
$$

$40-45$

$45-50$

$50-70$

$70-75$

$75-80$

$80-85$

$85-90$

$90-95$ 
Table 2.--Descriptions of cuttings from wells - Continued

$$
\text { Well C - Continued }
$$

Material

Depth interval (feet)

Silt, light-brown with smell limestone gravel-... 95-100

Pebbles, limestone, to $\frac{1}{2}$ inch, silt matrix ....... 100-110

Pebbles, to $\frac{1}{2}$ inch, sub angular, more silt

than above

$110-115$

Gravel, limestone, angular to broken to $1 / 8$

inch, trace silt

$115-125$

Silt, light-brown with pebbles to $\frac{1}{2}$ inch .......... 125-140

Silt, light-brown, sand and some small limestone

Gravel, cream, pebbles to $1 / 8$ inch

Silt, light-brown, some small gravel n-... 150-155

Silt, with broken limestone pebbles .

Pebbles, limestone, to $\frac{1}{2}$ inch, angular ......... 160-165

Silt, light-brown to cream with small gravel-.... 165-175

Silt, light-gray with small limestone gravel -.... 175-180

Silt, light-brown with pebbles to $\frac{1}{4}$ inch ........ 180-185

Silt, light-orown with pebbles to 1/8 inch -...... 185-190

Gravel, limestone, to 1 inch, angular to sub

angular, with some pebbles sub angular....... 190-195

Gravel, broken angular limestone fragments

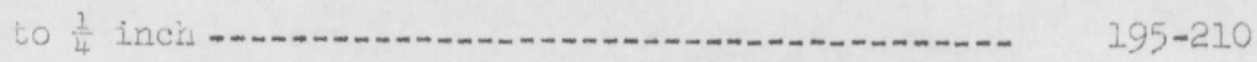


Table 2.--Descriptions of cuttings from wells - Continued

We11 C - Continued

Material

Depth interval ( feet)

Silt, light-brown, with ancular limestone

fragments to $1 / 8$ inch

Gravel, broken limestone framents to $\frac{1}{4}$ inch-... 215-240

Pebbles, limestone, with quartz sand,

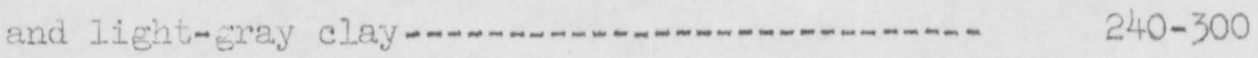

Pebbles, broken limestone fragments to $\frac{1}{4}$ inch-.. 300-305

Pebiles, limestone, with light-gray clay ........ 306-350

Clay, dark-gray, hard, with some quartz sand .... 350-363

Clay, tan, sandy, with sandy to granule size

particles of andesite and limestone-n......... 363-393

Pebbles, limestone, sub angular to broken

to $1 \frac{3}{4}$ inch

Sand, brown-purple, fine, with clay -............. 403-408

Pebibles, limestone, sub angular and broken

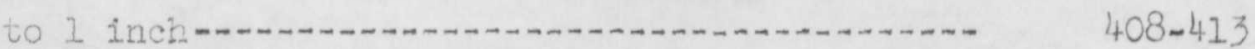

Sand, brown-purple, fine, with clay-............ 413-428

Sand, brown-purple, fine, with limestone

fragments - n.

Clay, magenta, and fine sand (Base of Bolson)-..- 448-453 
Table 2.--Descriptions of cuttings from wells - Continued

Well C - Concluded

Material

Depth interval (feet)

Rhyolite, medium-gray, altered and weathered

with some quartz and feldspar

$453-473$

Rhyolite, medium-gray, some fragments dark

gray, altered and weathered with some quartz

and feldspar

$473-503$

Rhyolite, as above, mostly dark-gray with

unweathered appearance

$503-653$

Clay or shale, redish-gray-nun

Clay or shale, brick-red

Clay or shale, gray-n...

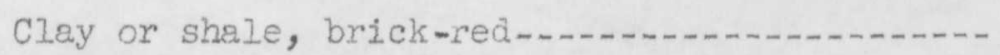

Rhyolite, same as 503-653

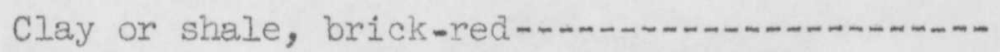

Clay or shale, dull-red

Rhyolite, mostly dark-gray

$653-558$

$658-663$

$663-668$

$668-678$

$678-683$

$683-688$

$688-698$

$698-703$

Rhyolite, reddish cast probably due to mud.....

$703-803$

Sand, gray to reddish-gray, fine, quartz, fragments

of volcanic rock and some red silt and clay;

may be erosional interval between two flows.-

$803-858$

Rhyolite, medium to dark-gray, unaltered....... 858-938

No sample taken $\quad 938-943$

Rhyolite, light-gray, altered, with fine sand -. 943-1,01l 


\title{
Table 2.--Descriptions of cuttings from wells - Continued
}

\author{
We1l D
}

Location: $\quad N E \frac{1}{4} S W \frac{1}{4} S W \frac{2}{4} \sec .12, T .20$ S., R. $3 \mathrm{E}$.

Material

Depth interval (feet)

Gravel, granule size, possibly silty and clayey,

rounded to angular, contains gray limestone, and

little red siltstone; little caliche-..........

$0-50$

Silt and clay, light-brownish-red-n....

$50-60$

Sandstone, light brownish-red and white, silty,

very calcareous, fine to very fine, medium-

cemented

$60-65$

Sandstone, light brownish gray, very calcareous,

dolomitic, coarse to fine, cemented, grades

locally to limestone

$65-80$

Gravel, pebbles, rounded to subrounded, mostly

limestone pebbles; thin limestone bed at

$83 \mathrm{ft}$.

Clay and silt, pale-red to redish-tan-....-

Sandstone, light brownish red to white, silty,

calcareous, fine to medium-

$105-110$ 
Teble 2.--Descriptions of cuttings from wells - Continued

$$
\text { We1. D - Continued }
$$

Material

Depth interval (feet)

Gravel, pebble size, silty, subrounded to rounded, pebbles mostly limestone and red sandstone-1.n$110-120$

Sandstone, brownish red, silty, argiliaceous(.), calcareous, fine to very fine.................. $120-125$

Gravel, consists of sandy limestone and coarse

to fine sandstone; little red sandstone $125-150$

Shale, medium-bluish-gray, partly pyritic-.....$150-160$

Siltstone, light purplish red, sandy, shaly, very slightly calcareous-... $160-173$

Gravel, granule size with fine pebbles of gray limestone, very sandy in lower part;

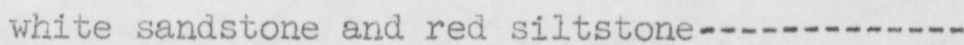
$173-190$ Sand, very light-gray, very clayey, slightly gravelly, very coarse-1. $190-200$

Clay and silt interbedded, meaium-gray to lightbrownish gray, contains brown limestone nodules and framents of limestone, sandstone, and bluish-gray shale-n-n $200-225$

Gravel, pebble size, very sandy, subrounded-.... $225-235$ 
Table 2.--Descriptions of cuttings from wells - Continued

$$
\text { We11 D - Continued }
$$

Material

Sand, light gray, quartzose, contains fragments

of white quartzite, bluish-gray shale, and

limestone

$235-240$

Shale, reddish-brown, red at top, silty, noncalcareous; trace of bluish-gray shale, interbedded(?) $240-265$

Sandstone, very light-gray to very lightgreenish-gray, silty, silightly glauconitic, quartzose, fine to very fine, hard, siliceous cement $265-285$

Sand, quartzose, coarse to very fine, very coarse, subrounded to rounded, few mica books (phlogopite?); little-bluish gray shale and red siltstone $285-312$

Shale, bluish-gray, non-calcareous ............. $312-316$ Sand, quartzose, fine to very fine, subangular, incoherent $316-328$

Shale, medium-gray, non-calcareous $328-337$

Sandstone, very light greenish gray, argillaceous, mostly silty, flauconitie, feldspathic, medium to fine, friable, siliceous cement; little purple shale interbedded $337-435$ 


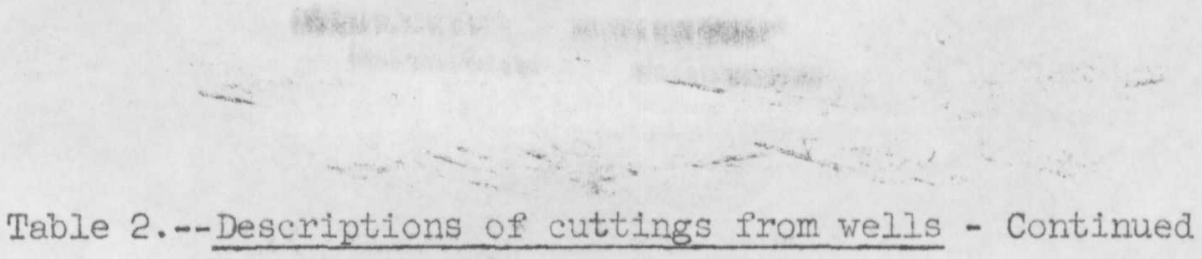

Well D - Continued

Material

Depth interval (feet)

Shale, medium to dark-gray, very silty, very samdy,

very slightly micaceous; few sandstones interbedded,

very light gray, silty, especially at 455 and

near base; little buff limestone

$435-510$

Sandstone, light-gray to very light-gray, silty,

glauconitic, medium to very fine, noncalcareous,

siliceous cement; very few partings(?) lavender

shale

$510-595$

Siltstone, dark-gray, very sandy, argillaceous,

part slightly pyritic, grades to silty shale

at base

$595-620$

Shale, dark-gray, very silty, sandy, hard, grades

from overlying unit_n 620-630

Shale, dark-gray, clay, slightly sandy-.............. 630-663

Sandstone, light gray, silty; little lavander,

reddish-brown clay; trace coal, pyritic-n-n-n-n-... 663-670

Shale, dark-gray, clay-no 670-685

Sandstone, light-gray, silty, argillaceous, very

fine to medium, calcareous, soft, contains dark

grains-0 685-690

Shale, medium to dark-gray, silty-n 690-695 


\title{
Table 2.--Descriptions of cuttings from wells - Continued
}

\author{
WeII D - Continued
}

Material

Depth interval (feet)

Sandstone, medium-gray, silty, argillaceous,

very fine to medium, soft 695-705

Shale, dark-gray, silty 705-709

Sandstone, medium fray, as above-.......... 709-713

Shale, dark-gray, silty, non-calcareous-n...- 713-730

Sandstone, light-gray, silty, argillaceous,

slightly calcareous, medium to very fine-...-. 730-742

Shale, dark-gray, silty $742-750$

Sandstone, light-gray, as above-n............. 750-760

1

Shale, dark-gray, silty

$760-764$

Sanästone, light-gray, argillaceous, silty,

medium grained, tight _................... 764-782

Shale, medium- to dark-gray, partly silty and sandy,

calcareous _........ $782-794$

Sandstone, silty, slightly calcareous, pyritic,

medium to fine grained $794-798$

Shale, medium-gray, silty, calcareous; little

lavender shale $798-806$

Sandstone, light-gray, silty, slightly calcareous,

medium to fine, pyritic-. 806-810 
Table 2.--Descriptions of cuttings from wells - Continued

Wel1 D - Continued

Material

Depth interval (feet)

Shale, medium-gray, silty, calcareous;

sandstone, as above $\quad$ 810-820

Sandstone, dark-gray, very argillaceous, silty,

fine

Shale, medium- to dark-gray, silty-............. 828-832

Sandstone, light greenish gray in upper part, light

gray in lower part, very silty, calcareous,

fine to very fine, little medium, contains

feldspar(?) and dark grains including glauconite,

partly micaceous and pyritic, hard, tight; gray

shale interbedded 867 to $872 \ldots \ldots+\ldots$

Shale, gray, silty $907-927$

Sandstone, medium-gray, very silty, argillaceous,

feldspathic, very fine to fine, angular ....... 927-950

Siltstone and shale, dark-pray, slightly

micaceous-aro 950-975

Shale, gray, very silty, micaceous 975-1,006

Sandstone, medium-gray, silty, feldspathic, very

fine to fine $\ldots 06-1,012$

Shale, dark-gray, slightly calcareous-n......... 1,012-1,038

Shale, gray, silty, calcareous 
Table 2.-Descriptions of cuttings from wells - Continued

Well D - Continued

Material

Depth interval (feet)

Shale, dark-gray, slightly calcareous.......... 1,080-1,095

Shale, gray, silty, calcareous; little

sandstone interbedded-...... 1,095-1,130

Siltstone, dark-gray, shaley, calcareous-........ 1,130-1,148

Shale, dark-gray, silty-n 1, 148-1,200

Shale, gray, very silty, very caleareous;

little limestone, dark brownish-uray, very

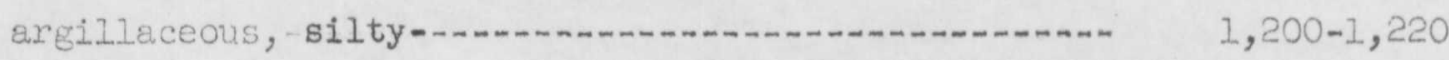

Shale, dark-gray, slightly calcareous-............ 1,220-1,240

Shale, black-1, 240-1,246

Shale, black, silty, slightly sendy, slightly

calcareous; trace of lavender to purple clay-....... 1,246-1,260

Anhydrite, pale grayish-tan, pyritic, micro-

crystalline; dolomite, tan, pyritic, speckled,

fine grained... 1,260-1,272

Shale and siltstone, dark brownish-gray,

dolomitic

Dolomite, dark brownish-gray; very calcareous, fine;

shale, pale greenish-gray, disseminated pyrite;

little lavender clay-n... 1,284-1,295 


\title{
Table 2.--Descriptions of cuttings from wells - Continued
}

\author{
Well D - Concluded
}

Material

Shale, dark-gray, silty, dolomitic

Sandstone, very pale-greenish-gray, s1lty, slightly

glauconitic, slightly pyritic, feldspathic, ,

very fine to medium; little siltstone, very

pale greenish gray
Depth interval (feet)

$1,295-1,308$

1, 308-1, 319

TD 


\section{WeI1 G}

Location: NE $\frac{1}{2} N E \frac{1}{4} S_{E} \frac{1}{4}$ sec. 15, T. 20 S., R. $3 \mathrm{E}$.

Material

Depth interval (feet)

No sample

Gravel, pebble size, sandy and silty near base--.-

Gravel, pebble size, little or no sand

Gravel, granule to pebble size, slightly sandy,

$$
\text { little caliche }
$$

Gravel, granule to pebble size, sandy, subangular, to angular; caliche; fine sand, especially in lower half of unit; little clay near top

Gravel, granule to pebble size, sandy, sand coarse in upper part and fine near base; caliche

Gravel, granule to pebble size, very little sand, limestone fragments predominate, also contains quartzite, chert, other; caliche $165-180$

Andesite or quartz latite, dark-gray, slightly weathered to reddish near top, some euhedral quartz, some "caliche" coating near top $180-200$ Andesite, gray to reddish, contains feldspar phenocrysts, caliche coating and clear calcite present- 200-250 
Table 2.--Descriptions of cuttings from wells - Continued

Well G - Continued

Material

Depth interval (feet)

Limestone, dark-gray, reddish-gray at top, finely

crystalline, contains calcite veinlets, very

clayey in lower 10 feet; few thin(?) red

sandstones interbedded between 280 and $315 \ldots$

$250-370$

Shale, reddish-brown, calcareous; limestone,

gray; little red sandstone

$370-380$

Limestone, dark-gray, dolomitic(?), finely

crystalline; shale, calcareous, dark red; gray

shale interbedded in lower 10 feet

$380-400$

Shale, gray, non-calcareous, non-fissile; very

little red shale interbedded below 440

$400-465$

Iimestone, argillaceous, gray to brownish-gray,

probably dolomitic

$465-475$

Shale, reddish-brown; little limestone and gray

shale interbedded

$475-485$

Shale, gray; limestone, dark-gray, mottled .....-

$485-490$

Limestone, dark-gray, finely crystalline, little

vein calcite; little gray, silty shale

$490-500$

Shale, medium to dark-gray, non-calcareous, non-

fissile; limestone, dark-gray, interbedded -..- 500-510

Shale, reddish-brown, slightly calcareous -..... 510-520 
Table 2.--Descriptions of cuttings from wells - Continued

Well G - Concluded

Material

Depth interval (feet)

Shale, medium-gray, non-calcareous; limestone,

argillaceous, medium-to dark-gray _......... 520-525

Iimestone, dark-gray, finely crystalline, little

vein calclte; very little red shale and red

sandstone

$525-560$

Iimestone, light-gray; shale, gray -.... 560-570

Limestone, dark-gray; shale, gray, near bottom -- 570-578 
Table 2.--Descriptions of cuttings from wells - Continued

Well H

Location: SW $\frac{1}{4} \mathrm{SW} \frac{1}{4} \mathrm{NE} \frac{1}{4} \mathrm{sec} .16, \mathrm{~T}, 20 \mathrm{~S} ., \mathrm{R}, 3 \mathrm{E}$.

Material

Gravel, dark-gray to black, 1 inch, sub-
$0-40$

Gravel, pebbles, sub-angular to angular

Gravel, pebbles, sub-angular to angular, with

light-brown clay

Depth interval ( feet)

Gravel, pebbles, sub-angular to angular, with

many broken angular fragments

$75-85$

Gravel, pebbles, sub-angular to angular with

$$
\text { clay }
$$

No sample

$$
85-120
$$

$120-140$

Silt, light-brown with broken gravel fragments

of dark-gray igneous rock

$140-145$

Silt, light-brown, with a few broken gravel

fragments

$145-150$

Silt, light-brown; no rock fragments

$150-155$

Silt, light-brown with a bery few broken gravel

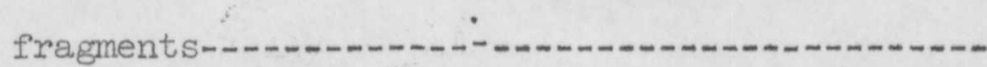


Table 2.-Descriptions of cuttings from wells - Continued

Well H - Continued

Material

Depth interval (feet)

Gravel, and some sand, multicolored; multicolored

particles range from $\frac{1}{2}$ inch pebbles to very

fine sand; few rounded particles most are bit-

cut fragments of dark-gray limestone, chert,

and volcanic rocks; some clay

$165-220$

Silt, light-brown, some rock fragments -...- 220-230

Silt, light-brown, many rock fregments

Gravel, particles are sub-angular to angular

to $\frac{1}{2}$ inch; some clay

Gravel, dark-gray, sub-angular to angular,

particle size ranges from silt to $\frac{1}{4}$ inch ...... 250-255

Gravel, finer than above with silt $\ldots$ 255-260

Gravel, dark-gray, angular to sub-angular,

no silt, to $\frac{1}{4}$ inch

Gravel, angular, to $1 / 8$ inch, with clay -...... 273-285

Gravel, light-gray, fine, igneous (andesite),

with biotite, feldspar, and rock fragments

from above (weathered) 285-290

Andesite, gray-green, weathered, with biotite,

feldspar - 290-335 


\section{Table 2.-Descriptions of cuttings from wells - Continued}

Well H - Concluded.

Material

Depth interval (feet)

Andesite, with biotite, feldspar, darker-gray

than above, unweathered appearance

Andesite, reddish-purple

Andesite, light-gray - 375-500

Samples in this interval were scanned during

cutting operations. No significant difference

in color or rock type was noted

$500-1,445$ 


\section{Table 2.--Descriptions of cuttings from wells - Continued}

\section{Well I}

Location: $\quad S W_{\frac{1}{4}} \mathrm{SW}_{\frac{1}{4}} \mathrm{SW}_{\frac{1}{4}} \mathrm{sec} \cdot 30, \mathrm{~T} \cdot 20 \mathrm{~S} ., \mathrm{R} \cdot 3 \mathrm{E}$.

Material

Soil, silt, and fine sand

Clay, light red, silt, and fine sand

Clay, sand, and sub-rounded pebbles

Send, clay, caliche and angular pebbles

Sand, gravel and clay

Send, clay, and gravel.

Gravel, clay and sand

Clay, fine sand and gravel

Clay and some gravel

Clay

Cley and fine sand

Clay

Clay and very fine sand

Clay

Clay and very fine sand

Clay and some gravel

Clay, hard

Clay and very fine sand

Sand and clay
Depth interval (feet)

$$
\begin{aligned}
& 0-10 \\
& 10-20 \\
& 20-35 \\
& 35-40 \\
& 40-45 \\
& 45-60 \\
& 60-80 \\
& 80-85 \\
& 85-100 \\
& 100-110 \\
& 110-115 \\
& 115-145 \\
& 145-150 \\
& 150-155 \\
& 155-235 \\
& 235-240 \\
& 240-245 \\
& 245-265 \\
& 265-270
\end{aligned}
$$


Table 2.-Descriptions of cuttings from wells - Continued

\author{
Well I - Continued
}

Material

Depth interval (feet)

Clay and some very fine sand

$270-310$

Clay

$310-350$

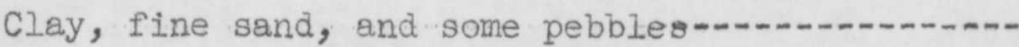

$350-375$

Clay, some fine sand

$375-380$

Sand, gravel and some clay

$380-385$

Sand, coarse, and gravel

$385-395$

Gravel, sand and clay

$395-400$

Clay, send and gravel

$400-405$

Gravel and some clay

$405-410$

Clay, fine sand, and some gravel

$410-415$

Gravel, sand, and clay

$415-420$

Gravel, coarse sand, and clay; some pebbles of

limestone, quartzite, and volcanic rocks _..... 420-470

Sand, coarse, and clay -... 470-475

Sand, coarse

$475-485$

Sand, coarse, and boulders

$485-510$

Sand, fine, and gravel

$510-515$

Sand, gravel, and boulders

$515-525$

Sand, fine, and gravel

$525-550$

Sand, fine, and boulders

$550-560$

Sand, fine, gravel and some clay

$560-565$

Gravel, fine sand and clay

$565-600$ 
Table 2.--Descriptions of cuttings from wells - Continued

Well I - Continued

Material

Gravel, coarse sand and clay

Gravel, sand and white to red elay

Gravel and clay

Clay, gravel, and sand

Gravel, sand and clay

Gravel and sand

Send, fine, and rounded pebbles

Sand, coarse, pebbles and some clay

Depth interval (feet)

$600-615$

$615-630$

$630-650$

$650-655$

$655-660$

$660-675$

$675-680$

$680-715$

Pebbles, multicolored, mostly dark

limestone and some rounded quartz

$715-735$

Same as 715-735 with more clay

Same às 715-735

$735-750$

$750-765$

Sand, fine (may be bit-ground), and pebbles

of limestone and volcanic rocks.

$765-770$

Sand, fine, quartz, well-rounded; particles of

rhyolite, andesite, chert and limestone,

some clay

$770-805$

Sand, coarse, rounded, quartz and volcanic rocks - 805-825

Sand, coarse, gravel and clay. A few rounded. 
Table 2.-Descriptions of cuttings from wells - Continued

\author{
Wel1. I - Concluded
}

Material

Gravel and coarse sand; rounded pebbles

Sand, coarse and clay; some rounded pebbles

Gravel, fine sand and clay

Sand, fine gravel and clay

Clay, sand and rounded pebbles

Sand, fine to coarse

Clay, and some sand, fine to coarse

Clay, dark red, and sand, fine to medium ......-

Clay, sand and gravel

Sand, coarse and clay

Clay, sand and fine gravel

Gravel, sand and clay

Clay, sand and gravel.
Depth interval (feet)

$840-870$

$870-900$

$900-930$

$930-935$

$935-940$

$940-955$

$955-960$

$960-965$

$965-970$

970-975

$975-980$

980-985

985-1,000 


\section{Well J}

Location: NW $\frac{1}{4} S E \frac{1}{4} N W \frac{1}{4} \mathrm{sec} .31$, T. 20 S., R. 3 E.

\section{Material}

Soil and very fine sand

Sand, coarse

Gravel, some sand and caliche

Gravel and sand

Gravel

Clay, tan, silty and very fine sand; some gravel

Gravel and sand; some clay

Sand, reddish-tan, clay and gravel

Clay, tan, with some sand and a few pebbles ....

Clay, tan

Clay, tan, pebbles and sana; gravel probably

thin bedded; some caliche .....................

Gravel and tan clay

Sand, very coarse, pebbles, and tan clay .......

Clay, tan, and gravel

Gravel and clay

Gravel, very coarse sand and clay
Depth interval (feet)

$$
\begin{aligned}
& 0-10 \\
& 10-15 \\
& 15-30 \\
& 30-35 \\
& 35-45
\end{aligned}
$$

$45-55$

$55-85$

$85-110$

$110-230$

$230-235$

$235-325$

$325-330$

$330-350$

$350-360$

$360-365$

$365-370$ 
Table 2.--Descriptions of cuttings from wells - Continued Well J - Continued

Material

Depth interval (feet)

Clay, pebbles and very coarse sand $370-385$

Gravel and clay $385-395$

Sand, well rounded, and clay $395-415$

Sand, gravel and clay $415-470$

Gravel, sand, and clay $470-525$

Sand, fine to coarse, gravel and clay $525-540$

Clay and very coarse, well rounded sand $540-550$

Sand, fine to coarse, gravel and clay $550-555$

Gravel, clay and sand $555-565$

Gravel and little clay, some sand; beds probably well cemented $565-665$

Sand, coarse, gravel and little clay $665-670$

Gravel and sand $670-680$

Sand, fine to coarse, gravel and clay $680-735$

(Bit and drill collars lost in hole; log continues on hole drilled 15 feet away)

Gravel, sand, and some clay-n. $735-745$

Sand, some gravel $745-750$

Gravel and clay $750-760$

Sand, very coarse and gravel $760-775$ Clay and fine to coarse sand $775-825$ Sand, medium to fine, some gravel and clay $825-830$ 
Table 2.--Descriptions of cuttings from wells - Concluded

WeII J - Concluded

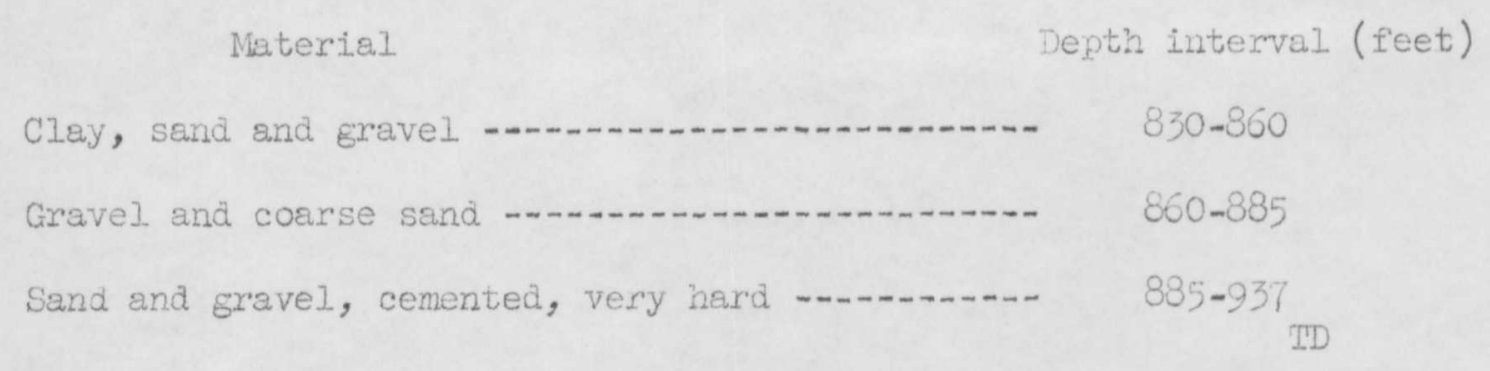




\section{Table 3.--Electric logs of wells $\mathrm{C}, \mathrm{D}, \mathrm{H}, \mathrm{I}$, and $\mathrm{J}$ in the Apol10 PSD facility, Dona Ana County, \\ N. Mex. (Logs are in pocket.)}

Electrical log of well C

$\begin{array}{lllll} & \text { " } & \text { " } & \text { " } & \text { D } \\ \text { " } & \text { " } & \text { " } & \text { " } & \text { H }\end{array}$

Induction-Electrical log of well I

Microlog of well I

Induction-Electrical $\log$ of well J

Microlog of well J 


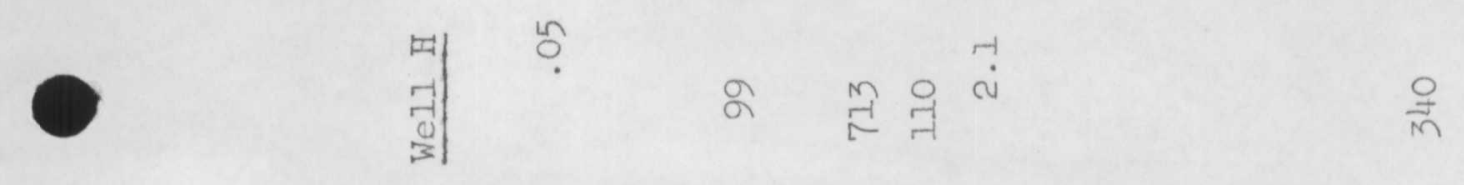
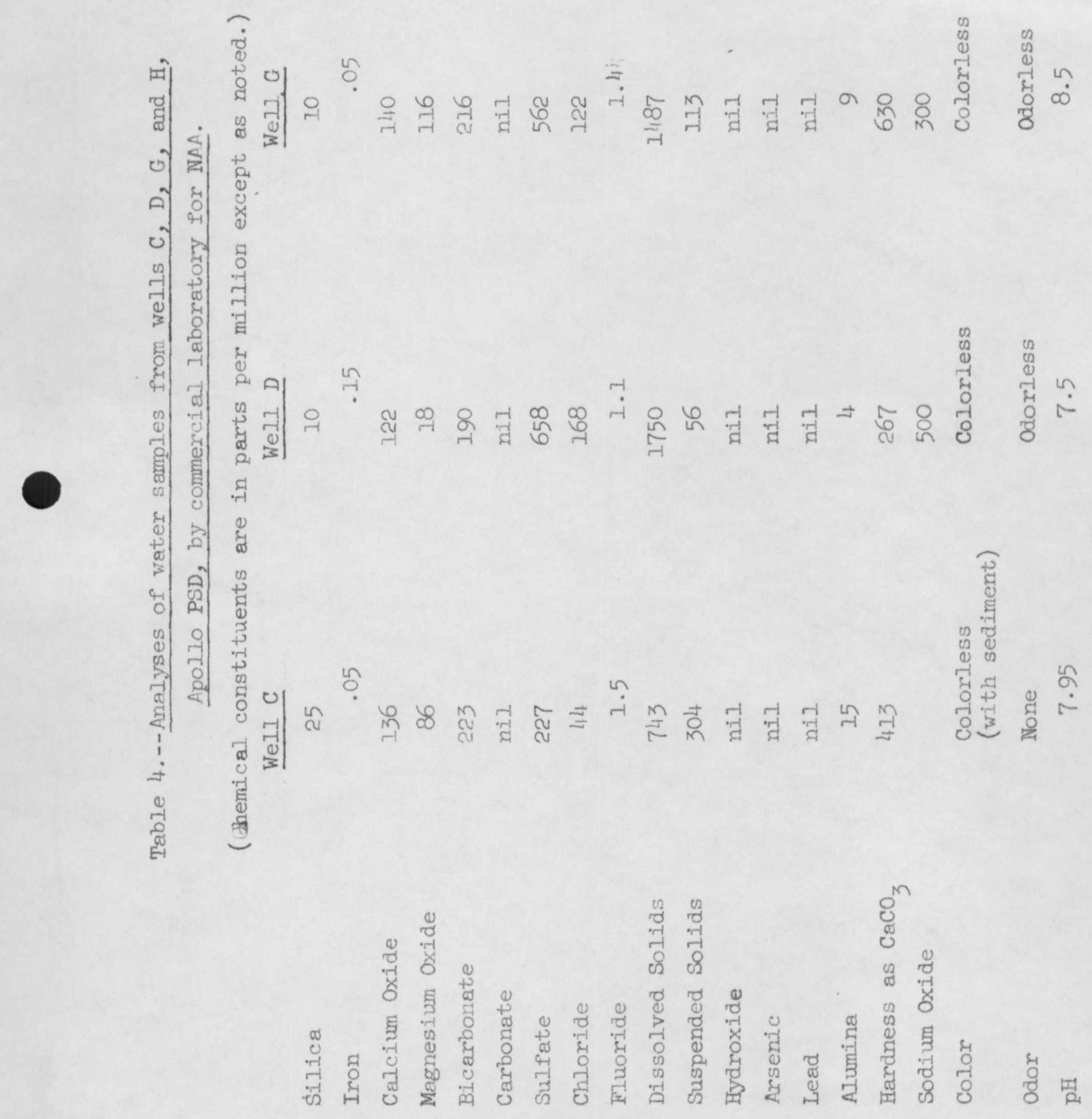


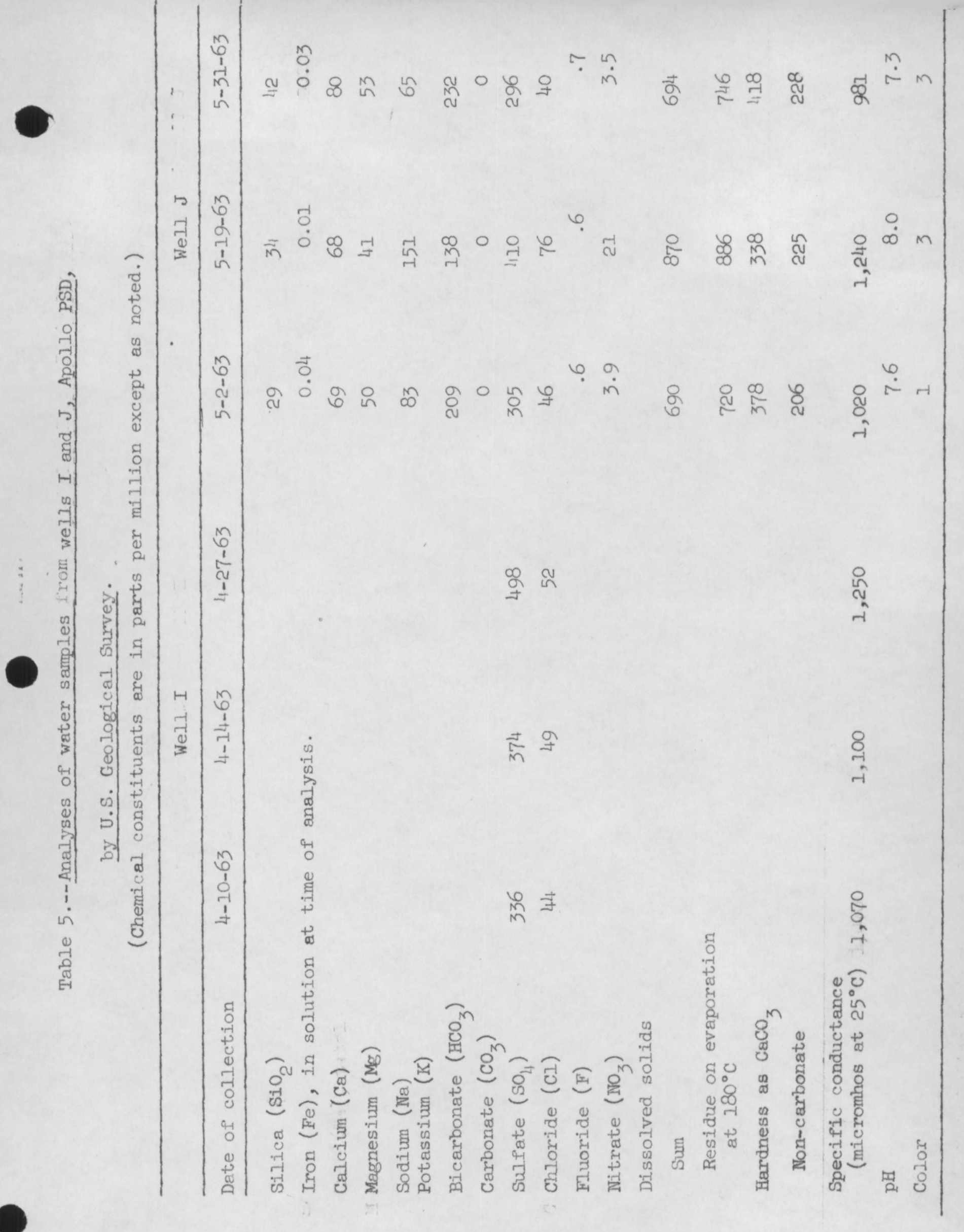




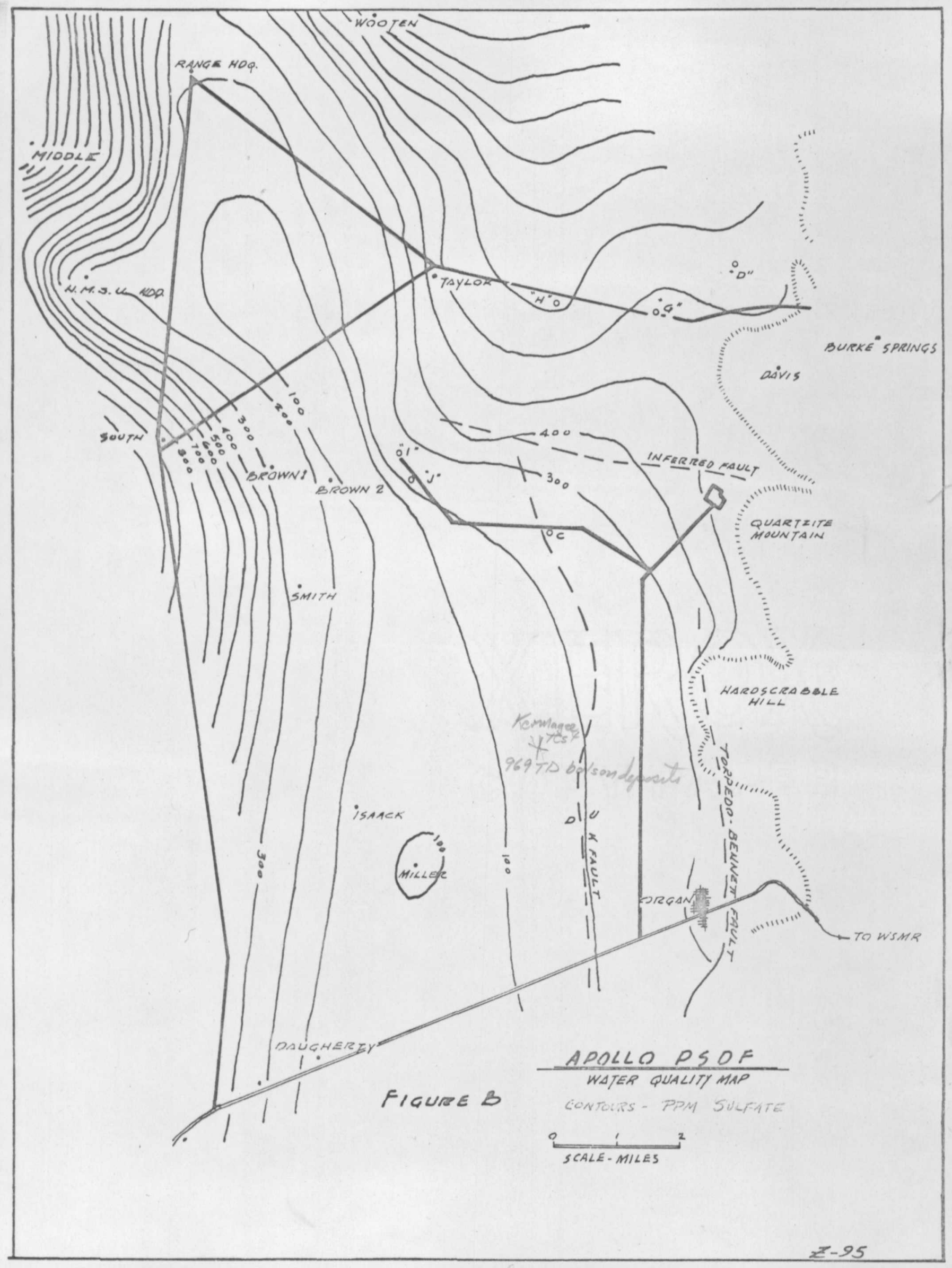


Water-Supply Development at NASA

Apollo Propulsion System Development facility

By

G. C. Doty

Table 3

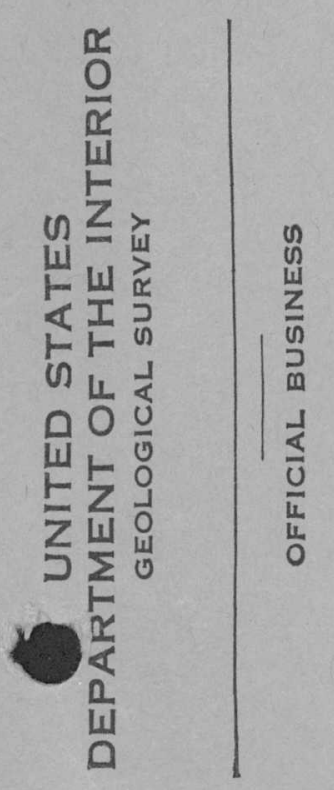

